IZA DP No. 6068

Can Higher Employment Levels Bring Lower Poverty in the EU? Regression Based Simulations of the Europe 2020 Target

Ive Marx

Pieter Vandenbroucke

Gerlinde Verbist

October 2011 


\title{
Can Higher Employment Levels Bring Lower Poverty in the EU? Regression Based Simulations of the Europe 2020 Target
}

\author{
Ive Marx \\ University of Antwerp \\ and IZA \\ Pieter Vandenbroucke \\ University of Antwerp \\ Gerlinde Verbist \\ University of Antwerp
}

\section{Discussion Paper No. 6068 \\ October 2011}

\author{
IZA \\ P.O. Box 7240 \\ 53072 Bonn \\ Germany \\ Phone: +49-228-3894-0 \\ Fax: +49-228-3894-180 \\ E-mail: iza@iza.org
}

Any opinions expressed here are those of the author(s) and not those of IZA. Research published in this series may include views on policy, but the institute itself takes no institutional policy positions.

The Institute for the Study of Labor (IZA) in Bonn is a local and virtual international research center and a place of communication between science, politics and business. IZA is an independent nonprofit organization supported by Deutsche Post Foundation. The center is associated with the University of Bonn and offers a stimulating research environment through its international network, workshops and conferences, data service, project support, research visits and doctoral program. IZA engages in (i) original and internationally competitive research in all fields of labor economics, (ii) development of policy concepts, and (iii) dissemination of research results and concepts to the interested public.

IZA Discussion Papers often represent preliminary work and are circulated to encourage discussion. Citation of such a paper should account for its provisional character. A revised version may be available directly from the author. 
IZA Discussion Paper No. 6068

October 2011

\begin{abstract}

\section{Can Higher Employment Levels Bring Lower Poverty in the EU?} Regression Based Simulations of the Europe 2020 Target

At the European level and in most EU member states, higher employment levels are seen as key to better poverty outcomes. But what can we expect the actual impact to be? Up until now shift-share analysis has been used to estimate the impact of rising employment on relative income poverty. This method has serious limitations. We propose a more sophisticated simulation model that builds on regression based estimates of employment probabilities and wages. We use this model to estimate the impact on relative income poverty of moving towards the Europe 2020 target of 75 percent of the working aged population in work. Two sensitivity checks are included: giving priority in job allocation to jobless households and imputing low instead of estimated wages. This paper shows that employment growth does not necessarily result in lower relative poverty shares, a result that is largely consistent with observed outcomes over the past decade.
\end{abstract}

JEL Classification: $\quad$ I32, J21, R28, J68

Keywords: employment growth, poverty, Europe 2020, household work intensity, low pay

Corresponding author:

Gerlinde Verbist

Herman Deleeck Centre for Social Policy

University of Antwerp

Sint-Jacobstraat 2

2000 Antwerp

Belgium

E-mail: gerlinde.verbist@ua.ac.be 


\section{Introduction}

The idea that employment growth and poverty reduction are natural and inseparable allies has long been central to the EU's strategic agenda. This notion was particularly central to the Lisbon Agenda and it remains at the core of the Europe 2020 Agenda, although there seems to be an implicit recognition now that higher levels of employment may not automatically bring better social inclusion outcomes.

Past experience teaches us that employment growth does not always affect the distribution of work across households in such a way as to reduce poverty. In many of the best performing countries in terms of employment growth, relative poverty rates for the working aged population have increased or remained stagnant (Cantillon, 2011). It is for that reason not self-evident that future employment growth will translate into better poverty and social inclusion outcomes, especially since the still to be included segments have weaker profiles.

The main objective of this paper is to gauge the likely impact on relative income poverty (according to the EU's own definition) of taking employment levels to 75 percent of the active population. We present results from simulation models that employ more sophisticated methodologies than have thus far been employed in the literature (Whiteford and Adema, 2007; Fritzell and Ritakallio, 2010). Hence, our purpose is in part substantive, in part methodological. Substantively, we are interested in getting estimates for a range of EU countries of the possible impact on poverty of employment growth to 75 percent of the active population, as envisaged by the EU. But we also want to contrast and assess alternative approaches to simulating those scenarios. Specifically, we want to assess the added value of regression based approaches over earlier used shift-share methods.

This paper starts with an overview of EU employment and poverty objectives. Next, we turn to the empirical evidence on the observed links between employment growth and poverty reduction. We then proceed to explain the methodology used in this paper and we highlight how this differs from the methods used in previous studies, which we also replicate. The results section contrasts the findings from the different methodologies and includes two further sensitivity tests. The final section considers the limitations of our method and suggests ways forward. 


\section{EU employment and poverty objectives}

\subsection{The EU's employment strategy}

Prior to the Treaty of Amsterdam, community employment policy was restricted to individual measures in the spheres of structural, social, education and youth policy. At the Amsterdam European Council in June 1997, a Title on Employment was included in the EC Treaty as well as the promotion of coordination between national employment policies as a new community task. In November 1997, the Luxembourg European Council added further substance in the form of annual employment guidelines, national employment action plans and a joint employment report (Luxembourg Process). Following the Special meeting of the European Council in Lisbon in March 2000, Member states agreed on the strategic goal of making the EU the most competitive, dynamic, knowledge and innovation-based economic area in the world by 2010.

A clear and substantial increase in the employment level was one of the main aims of the Lisbon Strategy. Employment levels in the EU were to increase from 61 percent in 2000 to 70 percent by 2010. Women's employment level was to grow from 51 percent to over 60 and the employment rate for older men and women (between 55 and 64) to 50 percent. In November 2003 an Employment Taskforce headed by former Dutch Prime Minister and chief architect of the famous Polder Model Wim Kok submitted its report entitled 'Jobs, jobs, jobs'. The Task Force was established by the European Heads of State and Government in response to concerns that Europe was failing to reach the Lisbon objectives. The Report re-established the case for giving overriding priority to employment growth, not just as an objective in its own right but also as a means for strengthening social cohesion. In 2005, a mid-review of the EES and a re-launch of the Lisbon Strategy took place, resulting in a first set of Integrated Guidelines.

In 2011, and despite a failure to reach the Lisbon targets in most Member states, ambitions remain unabashed. First among the headlines targets formulated in the Europe 2020 strategy is the objective to reaching an employment rate of 75 percent by 2020. Some countries have set even more ambitious national targets within this framework. 


\subsection{The EU's anti-poverty strategy}

The principle of subsidiarity has played a particularly important role in the domain of social policy. Policies to combat poverty were and remain first and foremost the responsibility of EU member states. For a long time, social policy at the EU level consisted mainly of declarations of principle on the one hand and limited-budget (relative to country level social spending) targeted actions on the other, e.g. the Regional Development Fund and the Social Fund.

The 1989 Community Charter of Fundamental Social Rights was the first real attempt at EU level social policy. But even the Social Chapter - minimalist as it was in the context of what already existed in the more advanced welfare states in the EU - ran into difficulties. A new impetus was given to EU social policy at the Lisbon and Nice Summits. There it was decided to advance social cohesion on the basis of an open method of coordination at the EU level. Within this framework, a pivotal role is given to so-called social indicators. These are a set of well-defined empirical measures which help to ascertain whether and to what extent progress has been made on the social policy front. At the time of the Nice summit the idea of setting an ambitious poverty reduction target was floated but also quickly abandoned.

It was at the Laeken Summit in 2001 that the Commission proposed seven indicators (Atkinson at al., 2001). Prominent among these were indicators pertaining to the distribution of income and poverty. In the meanwhile, the indicators have been amended and complemented, but the proportion of persons living in relative income poverty remains a prime indicator, be it that its validity in the enlarged EU context is increasingly questioned, with calls for additional measures of absolute or material deprivation.

The Europe 2020 Strategy that has recently come into force sets, for the first time, a specific target to be reached by 2020: "20 million fewer people in at risk of poverty and social exclusion". This target, however, is not exclusively defined in terms of the number of people living in relative poverty. It also includes the number of persons living in very low work intensity households and the number of persons who are materially deprived. Thus countries can, for example, opt to focus on increasing work intensity at the household level rather than on reducing relative poverty. However, if an increase in the number of people in low work intensity households were to result in an increase in the number of people living in relative poverty no progress will have been made towards reaching the target. 


\section{Employment and poverty}

For a long time, and especially under the Lisbon Agenda, a strong complementarity between employment and social cohesion objectives was assumed. This belief had its ideological roots in such doctrines as the "Third Way" or the "Active Welfare State (Giddens, 2000; Hemerijck and Visser, 1999; Kenworthy, 2008).

Employment and unemployment rates in the EU15 improved significantly between 1997 and 2007, when a major financial crisis prompted a wider economic recession. However, rising employment during the pre-crisis period did not bring lower poverty. Strikingly, some of the top performers in terms of employment growth actually experienced rises in their relative poverty rates, the Netherlands being a notable case (Marx, 2007). As the OECD (2009) shows for a wide set of countries, marked increases in employment rates between the mid 1990s and mid 2000s went in many countries accompanied with rising or stagnant poverty rates for the working age population. Cantillon (2011) also shows this to be the case for the EU15 over the 'Lisbon' decade.

There are two principal reasons why past job growth has not produced poverty declines: a) because past job growth has not sufficiently benefited poor people and b) because a job does not always pay enough to escape poverty. Let us consider both factors in a bit more detail.

First, most at risk of poverty are persons living in workless or near workless households (OECD, 2009; De Graaf-Zijl and Nolan, 2011). They face the highest poverty rates by far and they also tend to experience the most severe financial hardship (including their dependent children). The concentration of non-employment within the same households may be due to many factors (Gregg and Wadsworth, 2001 and 2008; Gregg, Scutella and Wadsworth, 2010). A correlation between the employment statuses of household members may reflect a tendency for individuals who share common characteristics to live together. Since persons with fewer educational qualifications typically experience higher unemployment and non-employment rates, households whose members all have a low level of educational attainment are likely to be over-represented among workless households. Household members are usually looking for work in the same local labour market and a depressed labour market will have a common impact on them. In addition, household members often have similar levels of education attainment. The disincentive effects of tax and benefit systems can also play a role. It is often the case that if one person gets a benefit, another person is punished if he or she accepts a job. To get out of this dependency trap, all members of the household must find a job simultaneously, which may be particularly hard if both partners have low educational attainment. 
This problem may be more severe in countries with extensive means-testing of welfare benefits based on family income.

In this light, it is perhaps not altogether surprising that employment growth has not produced commensurate drops in workless household rates. Job growth has in many countries resulted in more double or multi-earner households, but only to a very limited extent in fewer no earner households (Vandenbroucke and Corluy, 2012). This 'Matthew effect' in the benefits to job growth may have had the added effect of pushing up median income, and hence relative poverty thresholds, widening the distance between the stagnant bottom and the rising median.

A second reason why employment growth does not necessarily result in less poverty is that a job may not pay enough to escape poverty (Andreß and Lohmann, 2008). What poor jobless persons often require is not just a job, but a job that pays significantly more than their benefit. In the case of nonemployed poor persons living in a household with already one earner the additional income required to escape financial poverty may be quite limited. Indeed, a small part-time job may suffice (Maitre, Nolan and Whelan, 2012). For sole breadwinners the required income gain is often quite substantial. From an anti-poverty perspective, the issue is not just "making work pay" (i.e. tempting people to move out of dependency), but to make work pay sufficiently to make sure that a move from dependency to work also implies a move from poverty to an adequate living standard. The living standard of poor households with weak or no labour market attachment is often so far below the poverty threshold (especially in the case of single parents and child rich households) that it is quite possible that a job that pays significantly above the minimum wage will not suffice to lift them from poverty (Immervoll, 2007).

Long regarded as predominantly if not exclusively an 'Anglo-Saxon' problem, linked to weak labour market regulation, decentralized wage setting and low replacement benefits, in-work poverty has now become a EU-wide concern. Recent comparative empirical studies confirm in-work poverty to be a pan-European problem (Andreß and Lohmann, 2008; OECD, 2009; Frazer et al., 2011). Workers in countries like Germany, France, Sweden or Spain are as likely to be confronted with household financial poverty as those in Britain or Ireland. According to the SILC based EU Social Inclusion Indicators, the extent of in-work poverty in 2008 ranges from a low of 4-5 percent in countries like Belgium, Denmark, Finland and the Netherlands, up to 11-12 percent in Spain, Latvia, Poland and Portugal, 14 percent in Greece and 18 percent in Portugal. As many as a quarter to a third of working-age Europeans living in poverty are actually already in work. 


\section{Methodology and data}

Earlier studies have used shift-share analysis to gauge the potential impact on poverty of labour market participation shifts. In an eleven country study, Fritzell and Rittakalio (2010) show that a majority of OECD countries would have considerably lower poverty rates if they had a household labour participation (and socio-demographic) structure similar to Sweden's - the best performing country. Interestingly, however, the impact of boosting labour participation - especially double earnership - levels to Sweden's would have widely varying impacts, with some countries, like Germany or Canada, ending up with higher hypothetical poverty rates. A similar exercise by Whiteford and Adema (2006) relating to child poverty yields similar results; the poverty reduction pay-off to increased double earnership would be generally favourable, but the effect ranges from very strong in some countries to negligible elsewhere. De Beer (2007) uses another approach to disentangle the effect of employment growth in a Lisbon scenario (i.e. 70 percent of working age population) on poverty rates in which he decomposes poverty taking into account the differing poverty rates of work rich and work poor households.

Shift-share analysis is simple to perform because only poverty rates and the share of the subpopulations are necessary inputs. However, this type of analysis has its limits when using a relative poverty measure because it effectively assumes a constant poverty threshold. The likely increase in incomes due to the increase of the share of workers is not taken into account. Indeed, when more persons are at work, the resulting median will most likely be higher, which corresponds to a higher poverty threshold. Moreover, in shift-share analysis there is no allocation mechanism to indicate which unemployed or inactive persons are more likely to be employed in the new scenario. This makes it impossible to find out how jobs resulting from a shift in employment would be distributed between and within households. In what follows we conduct a similar shift-share analysis, by increasing the employment rate for $23 \mathrm{EU}$ countries for which the employment rate falls below the Europe 2020 target, to the level of 75 percent of the working age population (20-64 years old) using EU-SILC data from 2008. From the 27 European countries that take part in the EU-SILC 2008 survey, only four reach the Europe 2020 target (Iceland, Norway, Estonia and Sweden) and are left out of the analysis. The poverty rate in case of the Europe 2020 target is constructed as follows: for 75 percent of the working age population, the original poverty rate of working individuals is used. The fraction of the working age population needed to reach the target is taken from the share of unemployed persons and the remaining part - if there is any - is subtracted from the inactive population. For what is left of these subgroups, the original poverty rate is used. In sum, the original poverty rate is reweighted using the Europe 2020 target. We use the following definitions:

- Person at work: in part time or full time work. 
- Unemployed person: indicates not to be working at the time of the interview, that he/she is available for work in the next two weeks and finally he/she has actively been looking for work in the last 4 weeks.

- Inactive (other) person: all persons not at work or unemployed.

In this paper, the static results of the shift-share analysis are compared with those from a more sophisticated method which is regression based (RB). The RB model estimates participation probabilities as well as labour incomes for the share of jobless persons at working age needed to reach the Europe 2020 target. The allocation of simulated jobs comes from a labour supply function estimated on the working age population in each country. We adopt multinomial logit to estimate the probability of an individual at working age that is currently not working that he or she is working full time, part time or stays out of the labour market. For those without work a two step Heckman selection model (Heckman, 1979) is used to simulate the labour incomes separately for part time and full time work. In the multinomial logit we use the following independent variables: gender, age, age squared, a dummy for the presence of a partner, the number of children, the logarithm of all other incomes in the household apart from the labour income of the individual, the highest education obtained (in 4 categories), a dummy for the country of birth (EU as reference) and a dummy for limitations in daily activities (yes/no). To capture the variance of the dependent variables for men and women, we incorporate interaction terms between sex, age, the presence of a partner, the number of children and the country of birth.

In a second step, the logarithm of gross part time and full time wages is regressed separately on age and education dummies, again for individuals at working age. Gross wage would ideally be captured as an hourly wage, after which we should simulate the number of hours a jobless individual is likely to work. In EU-SILC, however, it is arduous to construct an hourly wage for most countries, and even impossible for others. Therefore, we define the gross wage as the earnings from employment during the income reference year (i.e. 2007) and refer to the monthly statement whether work was full or part time. This allows us to use the same model for all countries and the distinction between part and full time work can still be taken into account. For both the part time and the full time wage estimation, we apply a Heckman selection correction using the same right hand side variables as in the multinomial model. We predict gross part time wages for jobless individuals and allocate these wages to the highest (with respect to part time outcome) ranked jobless individuals at working age in the labour supply multinomial logit estimation. The same is done for full time work. The number of jobs needed to reach the Europe 2020 target is country specific and determines the number of simulated gross wages in each country. 
To determine the real net income change, it would be ideal to use a tax benefit microsimulation model which takes into account how changing incomes affect taxes and benefit entitlements. Figari, Salvatori and Sutherland (2010) simulate a decrease of employment using EUROMOD. However, it is currently not possible to do this for all 23 countries and, moreover, EUROMOD is not yet ready to simulate unemployment benefits with sufficient accuracy. Thus we choose to subtract all individual social benefits from gross income when an individual is simulated to get into a job. This means that all unemployment, old age, survivors', sickness and disability benefits are set to zero when a jobless individual receives a simulated gross wage. The calculation from gross to net wages follows an OLS regression using employee gross wages as dependent and the number of children, marital status (divorced, widowed, partner in household, other) and the presence of other jobs in the households as explanatory variables. In future applications, we hope to skip this last regression and do the grossnet conversion with a microsimulation model. The predicted difference between the net wage and the lost benefits is summed up to the household income. Household income is distributed over all household members and equivalized using the modified OECD scales. We call the RB model M1.

Relative income poverty is measured following the European convention, that is: all individuals that have an equivalent household income lower than 60 percent of the median equivalent household income, are considered to be at-risk-of-poverty. Throughout this paper we use the term "poverty" instead of at-risk-of-poverty. The cross-sectional weights from EU-SILC have been used for all calculations. Poverty rates are calculated using both a fixed (i.e. based on incomes before employment growth) and a floating (i.e. based on the new income distribution) poverty line.

The RB model reveals what the partial effect of an employment rise would be for relative poverty in European countries that do not (yet) reach the Europe 2020 target. The effect is partial because the employment rise we simulate is an outcome on the available current labour supply determinants of the country. In other words, we assume that the yearly earnings of the simulated jobs are determined in the same observable way as the earnings of existing jobs. Furthermore, we allow the labour supply probability to allocate the simulated jobs to the entire working age population. This effectively implies that existing differences between job rich and job poor households are reinforced. Ideally, we would also want to model some second round effects that are associated with job growth but that is clearly beyond the scope of this analysis. With those limits, the results we present are a first but substantial attempt to go beyond a simple shift-share analysis to empirically review how rising employment translates into relative poverty, also because of the added sensitivity analysis. 


\section{Results}

\subsection{The impact of job growth on poverty: a comparison of different approaches}

First, we compare the poverty effect on the active age population of simulating an increase in job growth to 75 percent using different approaches (see Figure 1). However, since employment growth causes poverty lines to shift in our regression based models the whole of the population is affected. Thus we also report results for the entire population, which can be found in Figure A.1 in Annex.

Figure 1. Poverty rates before and after increase of employment to $75 \%$ using shift-share and regression-based approach (fixed and floating poverty line), active age population

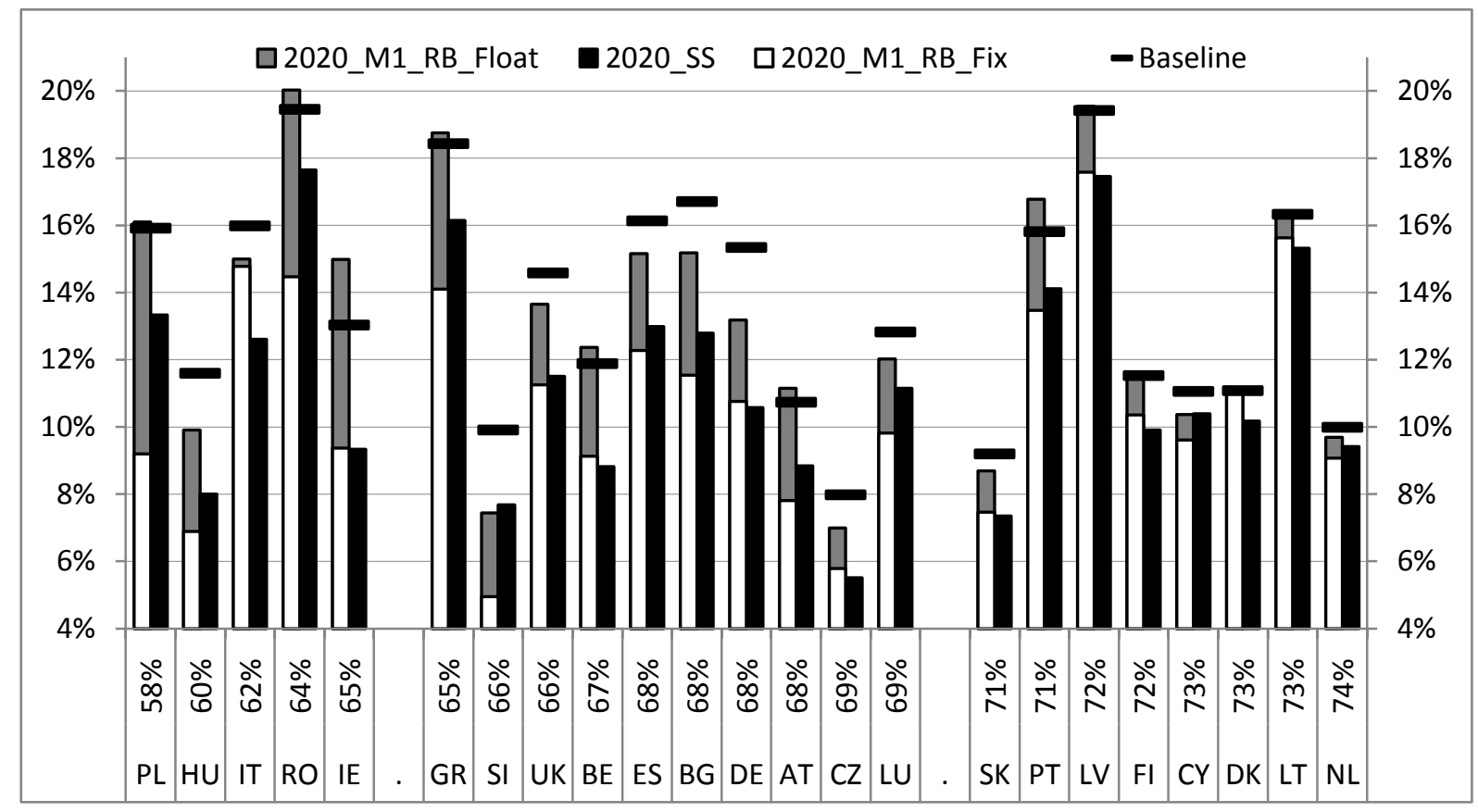

Baseline: current poverty rates; 2020_SS: poverty rates after increase of employment rates with shift-share methodology; 2020_M1_RB_Fix: poverty rates after increase of employment rates with RB methodology and poverty line fixed; 2020_M1_RB_Float: poverty rates after increase of employment rates with RB methodology and poverty line recalculated.

Countries are ranked from low to high current employment rates.

Source: own calculations on EU-SILC 2008.

Let us first look at the change in the poverty rate resulting from the increase in employment by reweighting, i.e. the shift-share analysis (2020_SS compared to the baseline). Overall, poverty decreases in all countries when the weight of the working population is increased. As can be expected, countries with a current employment rate that is already close to the Europe 2020 target experience the smallest drop in poverty (e.g. the Netherlands, Lithuania and Denmark). In the Czech Republic, Germany and Hungary, poverty decreases most strongly (a relative decrease of around 30 percent); Hungary is a country with a very low employment rate, whereas Germany and the Czech Republic are situated in the middle of the league. But overall, these results would lead us to the 
conclusion that increasing employment is a good anti-poverty strategy. However, the shift-share analysis does not take account of a number of factors, such as the characteristics of the currently inactive population.

These characteristics are explicitly considered with the RB methodology. With this method, individuals with the highest probability of having a job are given priority when assigning the status of being employed (part time or full time), as well as an income from work (see Section 4). In a first instance we keep the poverty line fixed, in order to be comparable with the shift-share analysis. As with the shift-share analysis, overall poverty drops in all countries, with small changes for highemployment countries. In most countries, the decreases are, however, more pronounced with this methodology. Especially in Poland and Hungary, poverty rates drop dramatically following the increase in employment. These two countries are the ones with lowest current employment rates, and apparently, with the regression-based method a considerable number of individuals are lifted out of poverty.

Using a fixed poverty line, however, disregards the change in the median income and thus in the poverty threshold that may occur when changing income levels. Switching from social transfers (or no income) to income from work, changes the relative income position of the individuals concerned, and may also cause the poverty line to shift if it is recalculated on the newly simulated income distribution. These changes in the poverty line are documented in Figure A.2 in Annex. The change in the poverty line is most pronounced in Poland and Romania, with rises there of more than 20 percent. Increases of between 10 and 20 percent occur in Hungary, Ireland, Greece, Slovenia, Spain, Bulgaria and Austria. In Denmark, Lithuania and the Netherlands, the poverty line is hardly affected, mainly because employment (and hence income) changes there are very small. With this floating poverty line, results are far less pronounced: in most countries poverty rates for the active population go down, but to a lesser extent than when a fixed poverty line is used. The largest decreases occur in Hungary, Slovenia, Germany and the Czech Republic, which are countries with low to average employment rates. In countries with a high employment rate, poverty hardly changes. In some countries, e.g. Ireland and Portugal, poverty even goes up, as a result of the upward shift of the poverty threshold.

Figure A.1 in Annex shows poverty rates for the overall population, also including households that are perhaps not affected by a change in employment, but who see their relative income position change following the simulated employment growth. With the floating poverty line, overall poverty in almost half of the countries drops, whereas in almost half of the countries poverty even increases. For instance in Ireland, poverty increases with around 25 percent, which is mainly due to the strong 
upward shift in the poverty line, worsening the relative position of groups like pensioners. Much depends here on where the hypothetically newly employed find themselves in the income distribution. In Hungary, by contrast, the simulated rise in employment does result in lower poverty because the upward shift in the poverty threshold is less pronounced.

Figure 2. Poverty impact of employment growth to $65 \%, 70 \%$ and $75 \%$ using regression-based approach (fixed and floating poverty line), active age population

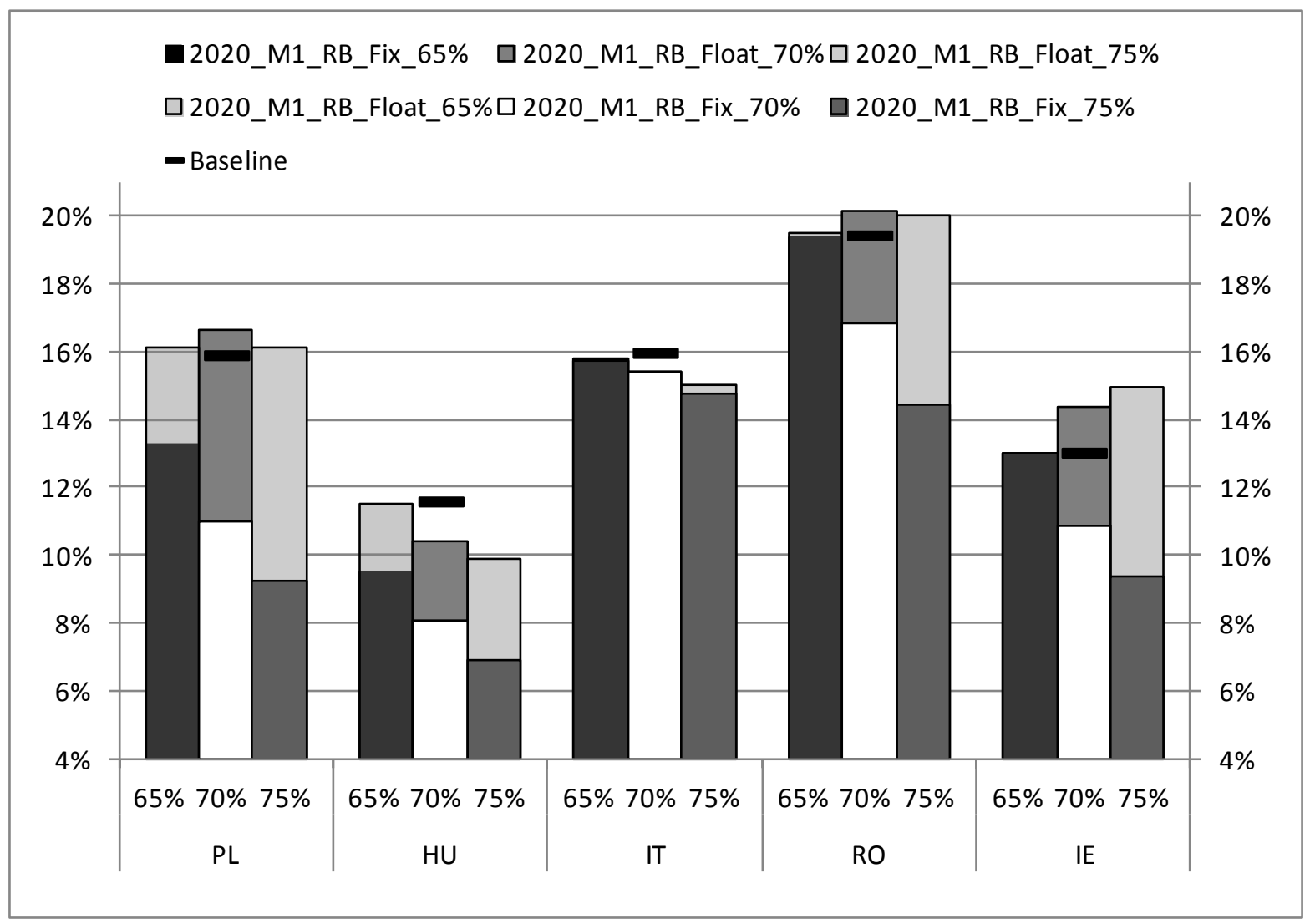

The lower end of each bar depicts the result using M1 and a fixed poverty line, while the top of the bar indicates the result using M1 and a floating poverty line.

Countries are ranked from low to high current employment rates.

Source: own calculations on EU-SILC 2008.

It can be argued that increasing the share of employed people to 75 percent at once is maybe too big a switch. Therefore, we also present poverty results for increases up to 65 percent, 70 percent and 75 percent employment rate, only for those countries that have an employment rate below 65 percent. We show the RB results for both a fixed and a floating poverty line. When a fixed poverty line is used, poverty among active age population decreases gradually as employment rises, as one would expect. However, with a floating poverty line, the pattern is very mixed. In Hungary and Italy, we still find this decreasing pattern, be it less pronounced. Poverty does not decrease in any country when moving to a 65 percent employment rate. In Poland, Romania and Ireland, an increase in poverty takes place when moving to a 70 percent employment rate, after which it falls back a little 
(except for Ireland). This direction change is due to the relative increases in the poverty line when more and more people are simulated to be working.

We have also calculated marginal changes (1 percent) in employment growth. The resulting percentage change in poverty rates can be found in Table A.1 in Annex. Surprisingly, 12 out of 23 countries face a positive poverty change after the marginal employment growth. This results from the fact that for these countries the poverty line already shifts after a 1 percent employment rise.

\subsection{Changing the allocation mechanism of the new jobs}

As already pointed out, the European Union sees the reduction of jobless households as an important factor in her anti-poverty strategy. According to our simulation, the share of jobless households that moves to one-earnership is, however, rather limited (see Figure 3); moves from jobless to two earners are even more rare. Most of the changes are moves from one to two earners in the household. Poland and Hungary are the countries in which most changes among originally jobless households take place; these are also the countries with the biggest simulated job growth.

Figure 3. Changes in household work intensity following job growth to $75 \%$ employment rate

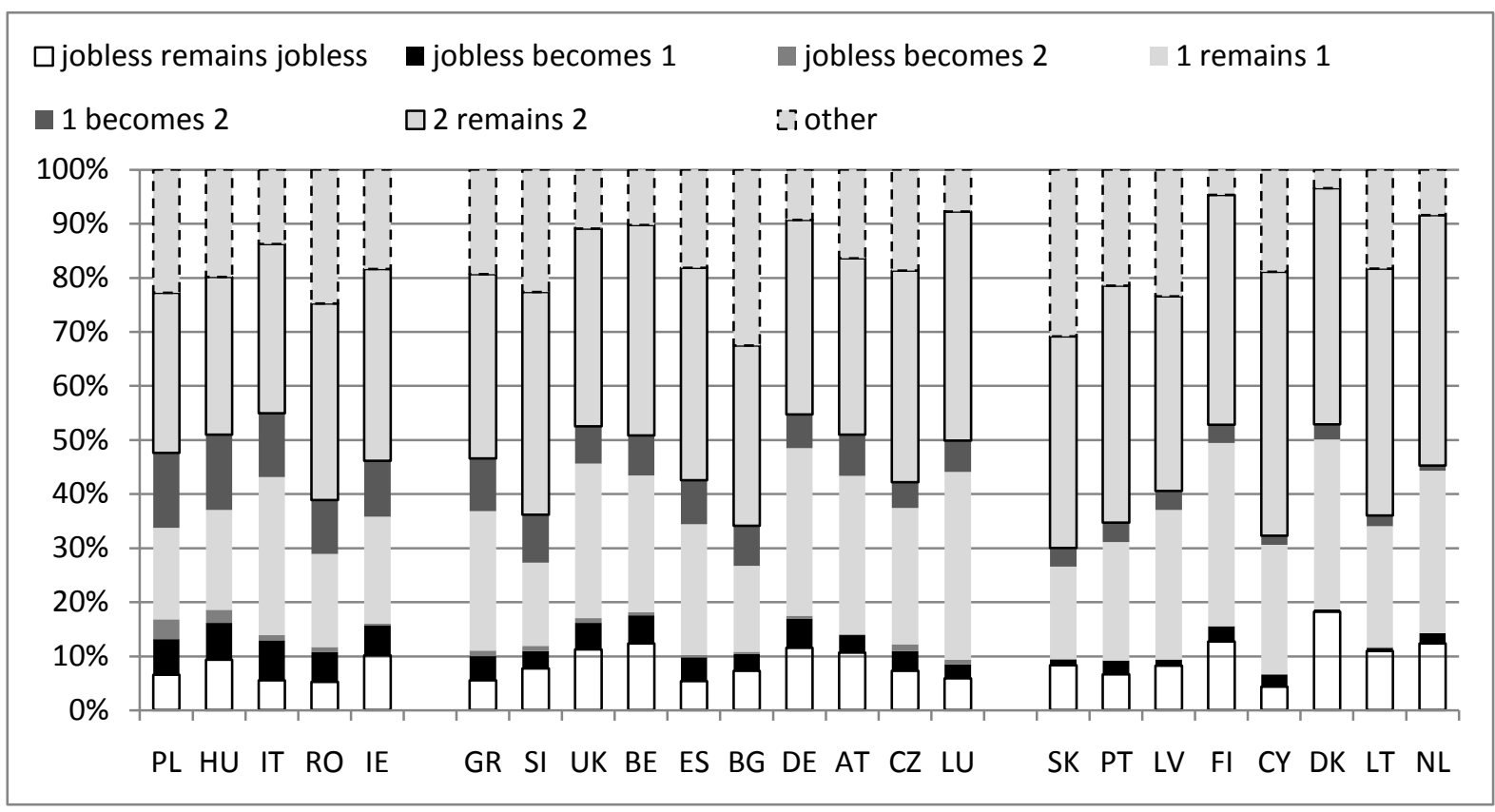

Countries are ranked from low to high current employment rates.

Source: own calculations on EU-SILC 2008.

Given these patterns, poverty outcomes may be dependent on the job allocation mechanisms explained in section 4 . Hence, we test the sensitivity by applying an alternative mechanism, namely 
by giving priority to individuals in jobless households (and from low to high work intensity if there are still jobs to be allocated after priority has been given to the jobless). Figure 4 gives the results for this simulation, which we will call S1. The results show that in the case of 14 counties, the S1 approach results in lower poverty rates compared to the regression based (M1) approach. This is true for both the fixed and the floating poverty line. Largest improvements in poverty outcomes are recorded in low-employment countries, such as Poland, Hungary, Romania and Greece. For other countries we even see a small rise in poverty rates when the S1 approach is used, which is most pronounced in Germany. Depending on the different characteristics of the simulated working population, simulated wages vary with a direct effect on poverty rates and an indirect on the poverty line when it is allowed to change. These results indicate that, apart from the job allocation mechanism, also the wage simulation mechanism plays an important role: many simulated workers seem to escape poverty, whether they are ranked according to the regression based model's outcome (M1) or according to work intensity of the household (S1). We test the sensitivity of the results for changes in the simulated wage level in the next section.

Figure 4. Poverty impact of employment growth to $75 \%$, sensitivity test for job allocation mechanism, active age population

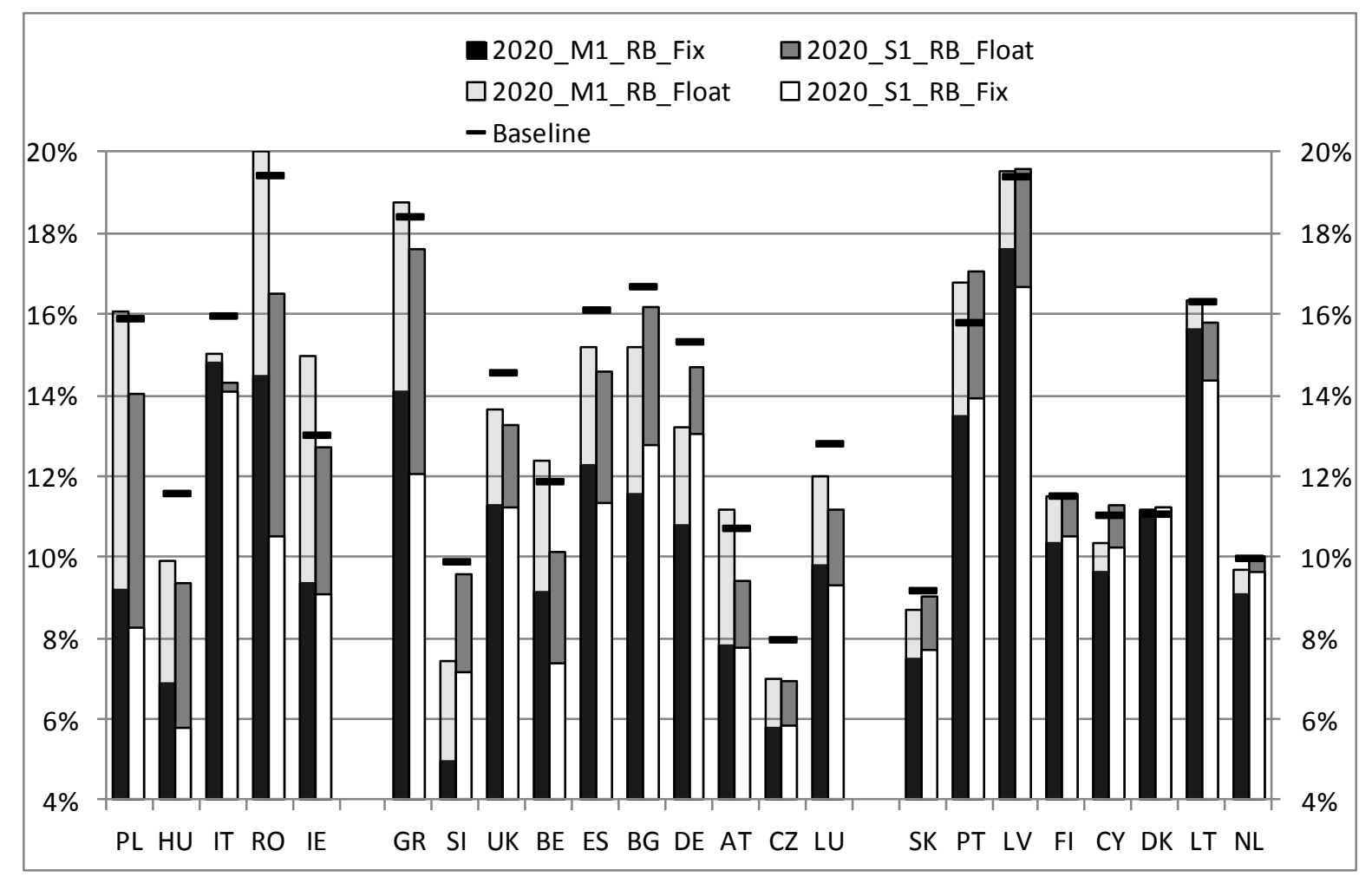

The lower end of each bar depicts the result using M1 and a fixed poverty line, while the top of the bar indicates the result using M1 and a floating poverty line.

Countries are ranked from low to high current employment rates.

Source: own calculations on EU-SILC 2008. 


\subsection{Changing the level of simulated wages}

Imputed wages for individuals that are predicted to get a job in our model are based on a Heckman estimation in M1 for full time and part time simulated workers separately. In Figure 5, we present average wage levels for the original workers and for the simulated workers in M1. For most cases, simulated wages tend to be smaller than the wages of the original working population. This does not come as a surprise, since non-employed individuals tend to have personal characteristics that make their simulated wages lower than the average worker.

Figure 5. Average original, simulated (M1) and low pay gross annual wages.

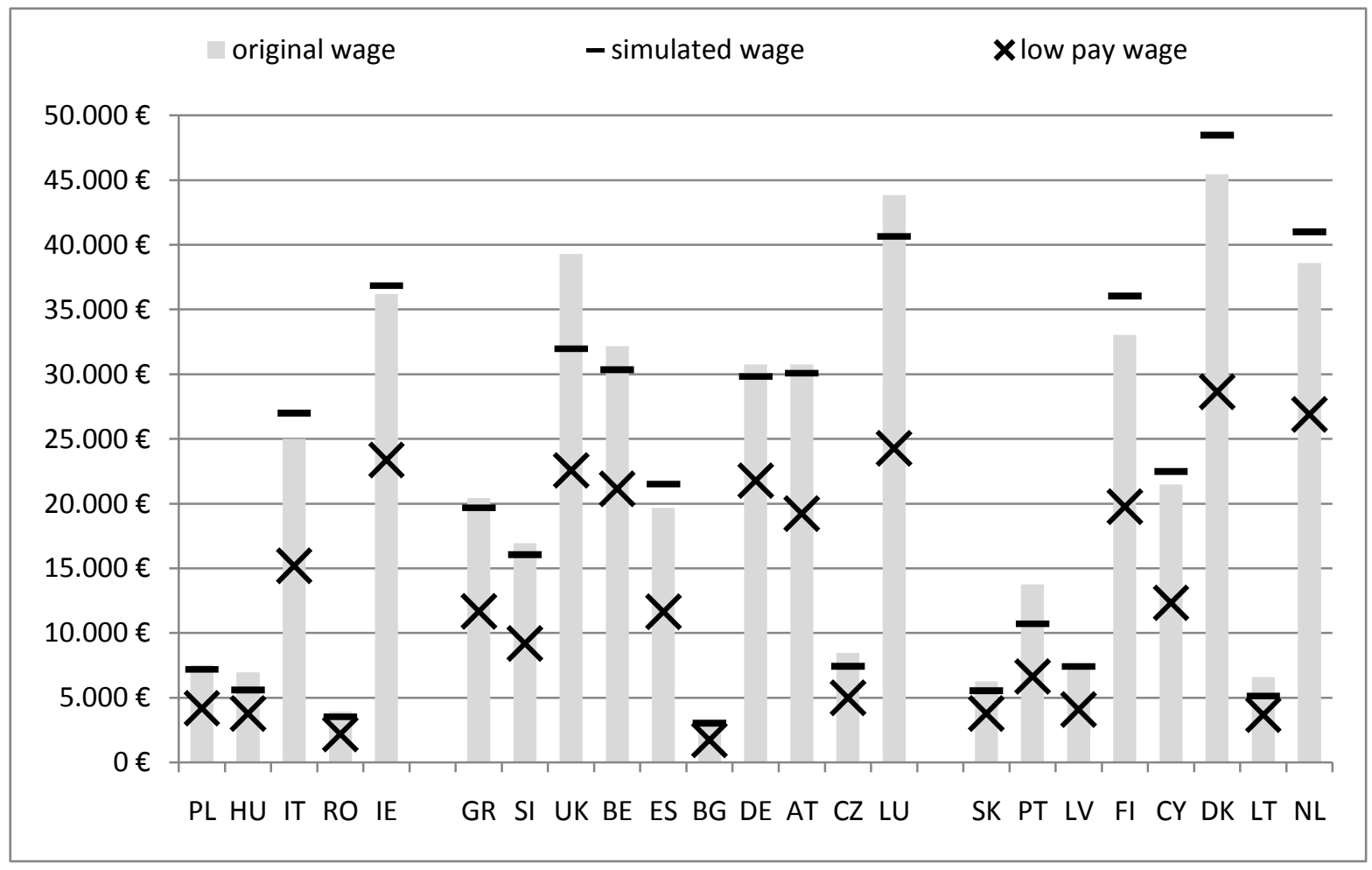

Monthly wages have been multiplied by 12 .

Countries are ranked from low to high current employment rates.

Source: own calculations on EU-SILC 2008.

Given these differences we test the sensitivity of our results to changes in the imputed wage level (S2). Instead of imputing the econometrically estimated wage level, we opt for a low wage. We choose a wage level that is commonly used as the benchmark to define a low wage, namely $2 / 3$ of the median full-time wage (Lucifora and Salverda, 2009). For all countries, this low pay measure is (far) below the average simulated and original wage, as is shown in Figure 5.

Consequently, with a fixed poverty line this alternative wage imputation (S2) results in poverty rates that are slightly higher or similar to those reported in M1 (see Figure 6). Only in Poland and Bulgaria larger increases in poverty can be found. However, with a floating poverty line, the poverty results are 
significantly affected in some countries. Imputing lower wages prevents the poverty line to shift upwards to the same extent as is the case with econometrically estimates wages, resulting in more favourable poverty outcomes. Compared to scenario S1, however, poverty reductions are less important, suggesting that the job allocation mechanism (i.e. giving priority to individuals in jobless households) has a somewhat larger impact on poverty reduction than providing a wage that is well above a relatively low wage.

Figure 6. Poverty impact of employment growth to $75 \%$, sensitivity test for changing the imputed wage level (regression-based approach, floating poverty line), active age population

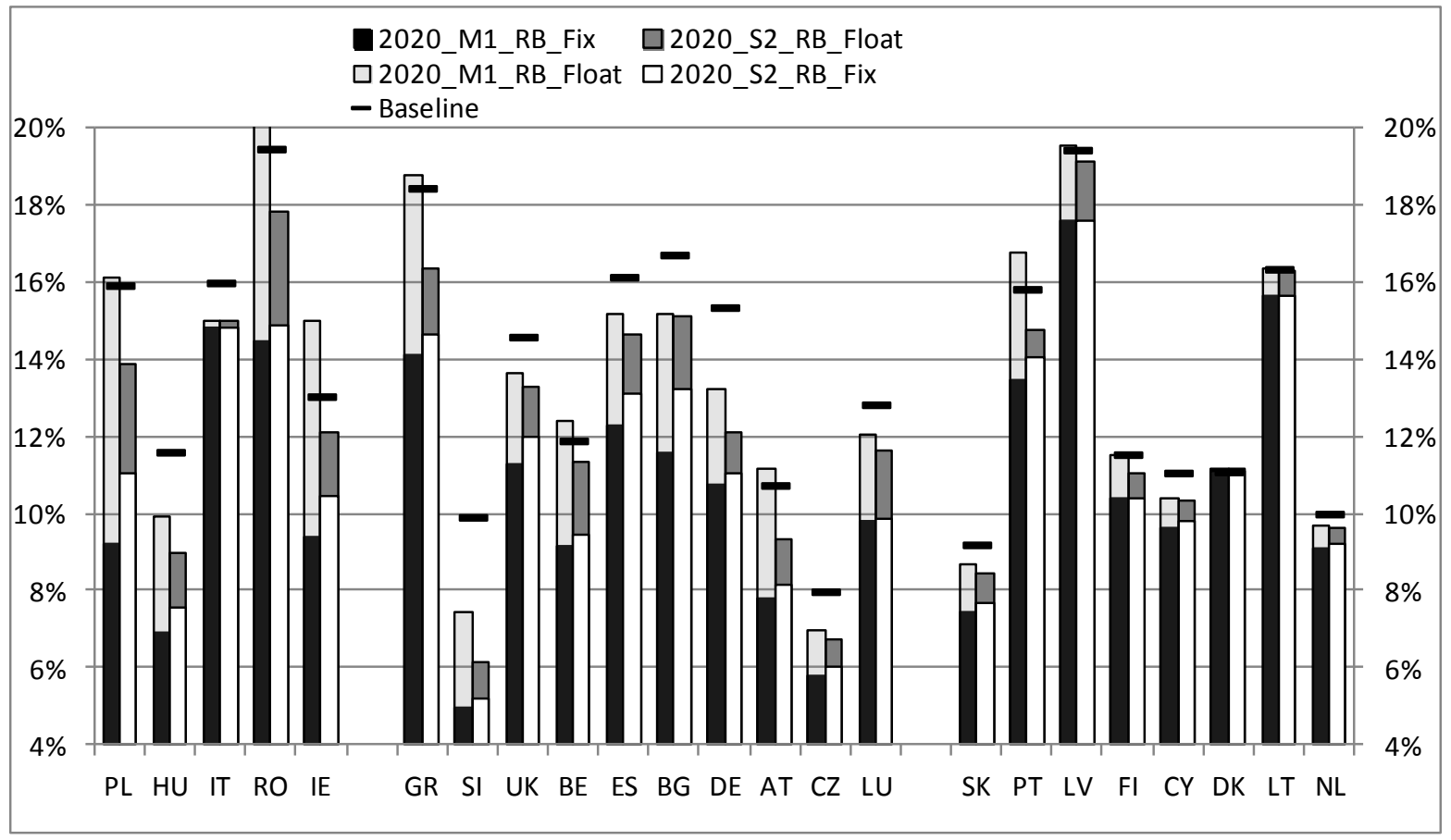

The lower end of each bar depicts the result using $\mathrm{M} 1$ and a fixed poverty line, while the top of the bar indicates the result using $\mathrm{M} 1$ and a floating poverty line.

Countries are ranked from low to high current employment rates.

Source: own calculations on EU-SILC 2008.

\section{Conclusion}

The idea that employment growth and poverty reduction are inseparable and effectively naturally complementary objectives remains by and large central to the EU's social and economic policy strategy (Europe 2020). Yet we now know that in the recent past employment growth has not produced the hoped for drops in poverty.

This paper supports the fact that relative poverty rates are difficult to predict when employment increases. Shift-share analysis - the reweighting of poverty rates method that has been used in the 
literature so far - tends to result in positive effects of employment growth on poverty. This paper confirms this. However, a regression based approach that takes account of employment probabilities and potential earnings yields more mixed and generally less positive results.

By accounting for possible changes in the poverty line, we go a step beyond static first round effects, thus distinguishing between the direct impact of increased employment and the indirect effect on the entire income distribution, an insight that is not provided by the shift-share analysis. In almost all of the countries analysed, poverty decreases, but much less than could be expected taking into account the large employment shifts. Interestingly, almost all individuals that get a job in our simulations move out of poverty. However, due to changes in the poverty line, overall poverty rates do not necessarily follow suit. Employment growth improves the income position of some individuals, especially those that actually get jobs, but it also causes the relative position of others to deteriorate, ceteris paribus. Much depends on where in the overall income distribution the newly created jobs end up, and that is not always predominantly in the bottom half of the distribution. To test for the sensitivity of our regression based outcomes, we have introduced two alternative specifications. First, we change the allocation mechanism, diverting the simulated jobs to work poor households first. Second, we alter the wage estimation by imputing a low pay wage. The second alternative does not change results to a large extent, while the first alternative causes relative poverty to decrease more strongly.

It is clear that whilst taking a step forward in modelling the impact of employment growth on poverty, the regression based method remains subject to limitations and caveats. The impact of employment growth on household incomes and the level of the poverty thresholds is estimated as a partial secondround effect. This is unrealistic since employment growth of the magnitude we simulate may well be unfeasible except when accompanied by macro-economic policies like overall wage moderation. On the other hand, tightened labour markets may boost wage demands. Many other second-round effects, including on labour supply, family formation etc., are thinkable and in effect plausible. General equilibrium type modelling in this area is the ideal to be aimed for but clearly the challenges remain quite formidable. Yet what this first attempt at sophistication shows is that the impact of employment growth on relative poverty rapidly becomes more complex and in some cases more counterintuitive once one moves beyond the reweighting techniques hitherto used in the literature. It also illustrates the problematic character of the relative poverty measure.

The analysis presented in this paper can realistically be improved in a number of ways. As already indicated, micro-simulation modelling can result in more refined gross-to-net transitions, as well as a more detailed calculations of the effects of changes in labour income on the tax-benefit position of the 
household. As micro-simulation models like EUROMOD are being expanded to more countries and more benefits (more specifically unemployment benefits) prospects are promising.

\section{Bibliography}

Andreß, H.-J. and Lohmann, H. (2008) The Working Poor in Europe. Employment, Poverty and Globalization. Edward Elgar Publishing Limited.

Atkinson, A., Cantillon, B., Marlier, E. and Nolan, B. (2001) Social Indicators: The EU and Social Inclusion. Oxford: Oxford University Press.

Cantillon, B. (2011) 'The paradox of the social investment state; growth, employment and poverty in the Lisbon Agenda', European Journal of Social Policy (forthcoming).

De Beer, P. (2007) 'Why work is not a panacea: a decomposition analysis of EU-15 countries', Journal of European Social Policy 17 (4): 375-388.

De Graaf-Zijl, M. and Nolan, B. (2011) Household joblessness and its impact on poverty and deprivation in Europe. GINI Discussion Paper 5, January 2011.

Figari, F., Salvatori, S. and Sutherland, H. (2010) Economic downturn and stress testing European welfare systems. EUROMOD Working Papers EM4/10, EUROMOD at the Institute for Social and Economic Research.

Fraser, N., Gutiérrez, R., \& Peña-Casas, R. (Eds.). (2011). Working Poverty in Europe: A Comparative Approach. Bakingstoke: Palgrave Macmillan.

Fritzell, J. and Ritakallio, V. M. (2010) 'Societal Shifts and Changed Patterns of Poverty', International Journal of Social Welfare 19, S25-S41.

Giddens, A. (2000) The third way and its critics. Cambridge: Polity Press.

Gregg, P. and Wadsworth, J. (2001) 'Everything You Wanted to Know about Workless Households but were afraid to Ask: Worklessness and Polarisation at the Household Level', Oxford Bulletin of Economics and Statistics 63, special issue.

Gregg, P. and Wadsworth, J. (2008) 'Two sides to every story: measuring polarization and inequality in the distribution of work', Journal of the Royal Statistical Society 171 (4): 857-875.

Gregg, P., Scutella, R. and Wadsworth, J. (2010) 'Reconciling workless measures at the individual and household level. Theory and evidence from the United States, Britain, Germany, Spain and Australia', Journal of Population Economics 23: 139-167.

Heckman, J. (1979) 'Sample selection bias as a specification error', Econometrica 47, 153-61.

Hemerijck, A. and Visser, J. (1999) 'The Dutch Model: an obvious candidate for the 'Third Way', European Journal of Sociology 42 (1): 229-231.

Immervoll, H. (2007), Minimum Wages, Minimum labour Costs and the Tax Treatment of Low-Wage Employment, OECD Social, Employment and Migration Working Papers No. 46, OECD, Paris, $23 p$.

Kenworthy, L. (2008) Jobs with Equality. Oxford: Oxford University Press.

Lucifora, C. and Salverda, W. (2009) 'Low Pay' in W. Salverda, B. Nolan and T. Smeeding (eds) Oxford Handbook of Economic Inequality. Oxford: Oxford University Press. 
Maitre, B., Nolan, B. and Whelan, C. (2012) 'Low Pay, In-Work Poverty and Economic Vulnerability: an analysis using EU SILC', The Manchester School (forthcoming).

Marx. I. (2007) 'The Dutch Miracle Revisited: The Impact of Employment Growth on Poverty', Journal of Social Policy 36 (3): 383-397.

OECD (2009) Employment Outlook. Paris: OECD.

Vandenbroucke, F. and Corluy, V. (2012) 'Household joblessness' in B. Cantillon and F. Vandenbroucke (eds) The Social Investment State. Oxford: Oxford University Press.

Whiteford, P. and Adema, W. (2007) What works best in reducing child poverty: a benefit or work strategy? OECD Social Employment and Migration Working Papers, No. 51. Paris: OECD. 


\section{Annex}

Figure A.1. Poverty rates before and after increase of employment to $75 \%$ using shift-share and RB approach (fixed and floating poverty line), entire population, poverty line at $60 \%$ of median equivalent income, 2008

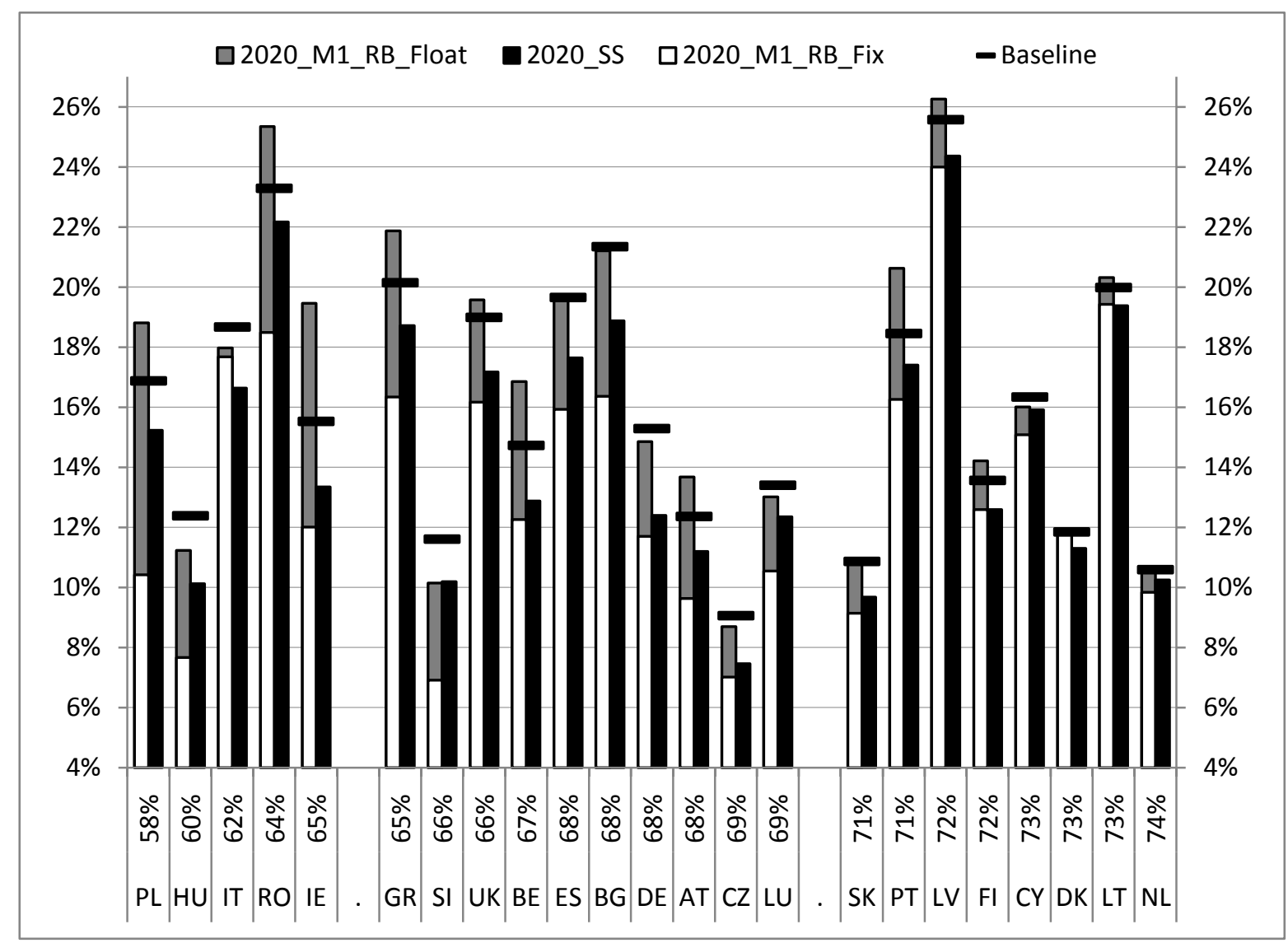

Baseline: current poverty rates; 2020_SS: poverty rates after increase of employment rates with shift-share methodology; 2020_RB_Fix: poverty rates after increase of employment rates with RB methodology and poverty line fixed; 2020_RB_Float: poverty rates after increase of employment rates with RB methodology and poverty line recalculated. Countries are ranked from low to high current employment rates.

Source: own calculations on EU-SILC 2008. 
Figure A.2. Poverty thresholds used in the analysis (60\% of median equivalised income), single person.

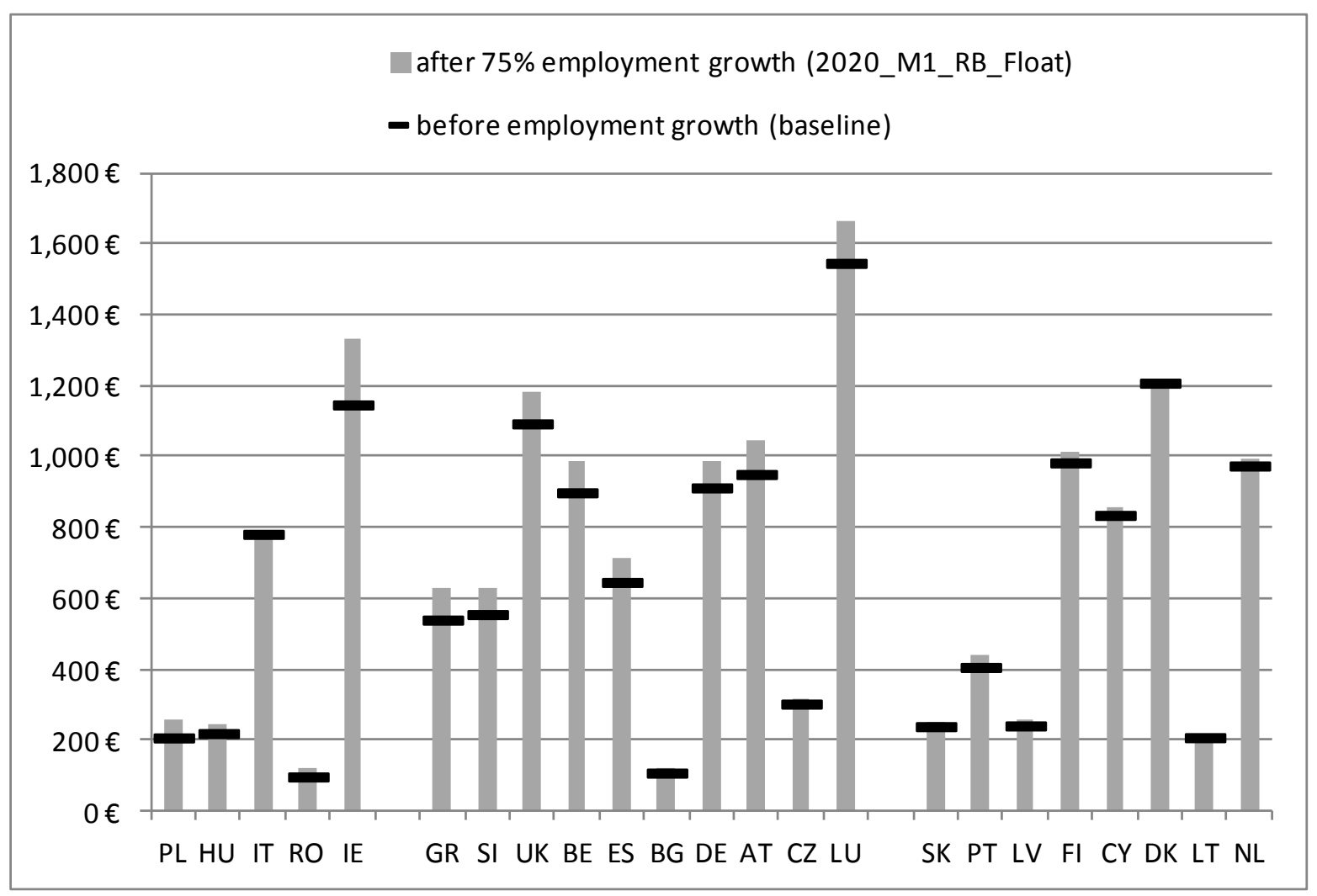

Countries are ranked from low to high current employment rates.

Source: own calculations on EU-SILC 2008. 
Table A.1. Poverty change (in \%) following a 1\% employment increase in RB model

\begin{tabular}{|c|c|}
\hline & $\begin{array}{l}\% \text { change in poverty after } 1 \% \text { increase in employment in } \\
M 1 \text {, using a floating poverty line, active age population }\end{array}$ \\
\hline$\overline{P L}$ & $0.56 \%$ \\
\hline $\mathrm{HU}$ & $-0.63 \%$ \\
\hline IT & $-0.27 \%$ \\
\hline RO & $0.51 \%$ \\
\hline $\mathrm{IE}$ & $1.52 \%$ \\
\hline $\mathrm{GR}$ & $0.78 \%$ \\
\hline $\mathrm{SI}$ & $0.35 \%$ \\
\hline UK & $0.04 \%$ \\
\hline $\mathrm{BE}$ & $2.66 \%$ \\
\hline ES & $-0.73 \%$ \\
\hline$B G$ & $-2.56 \%$ \\
\hline $\mathrm{DE}$ & $-0.40 \%$ \\
\hline AT & $-2.16 \%$ \\
\hline $\mathrm{CZ}$ & $-1.30 \%$ \\
\hline LU & $-2.00 \%$ \\
\hline SK & $-2.28 \%$ \\
\hline PT & $5.34 \%$ \\
\hline LV & $0.10 \%$ \\
\hline $\mathrm{FI}$ & $1.60 \%$ \\
\hline $\mathrm{CY}$ & $-1.66 \%$ \\
\hline DK & $0.18 \%$ \\
\hline LT & $0.25 \%$ \\
\hline $\mathrm{NL}$ & $-2.18 \%$ \\
\hline
\end{tabular}

Countries are ranked from low to high current employment rates.

Source: own calculations on EU-SILC 2008. 